Sexual Warfare in the Silent Cinema: Comedies and Melodramas of Woman Suffragism Author(s): Kay Sloan

Source: American Quarterly, Vol. 33, No. 4 (Autumn, 1981), pp. 412-436

Published by: The Johns Hopkins University Press

Stable URL: http://www.jstor.org/stable/2712526

Accessed: 18-06-2015 17:56 UTC

Your use of the JSTOR archive indicates your acceptance of the Terms \& Conditions of Use, available at http://www.jstor.org/page/ info/about/policies/terms.jsp

JSTOR is a not-for-profit service that helps scholars, researchers, and students discover, use, and build upon a wide range of content in a trusted digital archive. We use information technology and tools to increase productivity and facilitate new forms of scholarship. For more information about JSTOR, please contact support@jstor.org. 


\title{
SEXUAL WARFARE IN \\ THE SILENT CINEMA: \\ COMEDIES AND MELODRAMAS \\ OF WOMAN SUFFRAGISM
}

\author{
KAY SLOAN \\ The University of Texas, Austin
}

IN THE DAYS BEFORE MOVIES COULD TALK, SILENT FILMS SPOKE clearly of sexual politics. As early as 1898 , a short primitive film called The Lady Barber caricatured a woman suffragist who commandeered a barber shop and, with the zeal of a latter-day Delilah, began snipping the hair of bewildered men. The young film industry soon discovered a wealth of entertainment material in the votes-for-women movement. After the turn of the century, comedies, melodramas, and newsreels brought the woman suffrage movement onto the nation's nickelodeon screens. As state after state refused to grant women the vote, suffragism foundered at the beginning of the twentieth century, and film satires persistently told their audiences that women belonged in the home, not in the voting booth. Newsreels sensationalized the movement while comedies featured the antics of man-hating suffragists, bumbling husbands, and confused children. Melodramas warned of the sweeping peril of suffragism, when their brazen film heroines ruined family life and devastated their communities. The antisuffrage films echoed the vehement cries of politicians, journalists, and preachers who feared that woman suffrage would spell the death of femininity and the family.

Dedicated suffragists, however, refused to let the cinematic ridicule go unanswered. Though the first decade of the twentieth century was one of scant political gain for their cause, the suffragists waged a battle that moved from churches and town meeting halls into movie houses. In 1912, 1913, and 1914, the National American Woman Suffrage Association and the Women's Political Union produced three melodramas and a comedy, all starring beautiful suffragist heroines who combined political activity with romantic and family interests. The antisuffrage comedies and the 


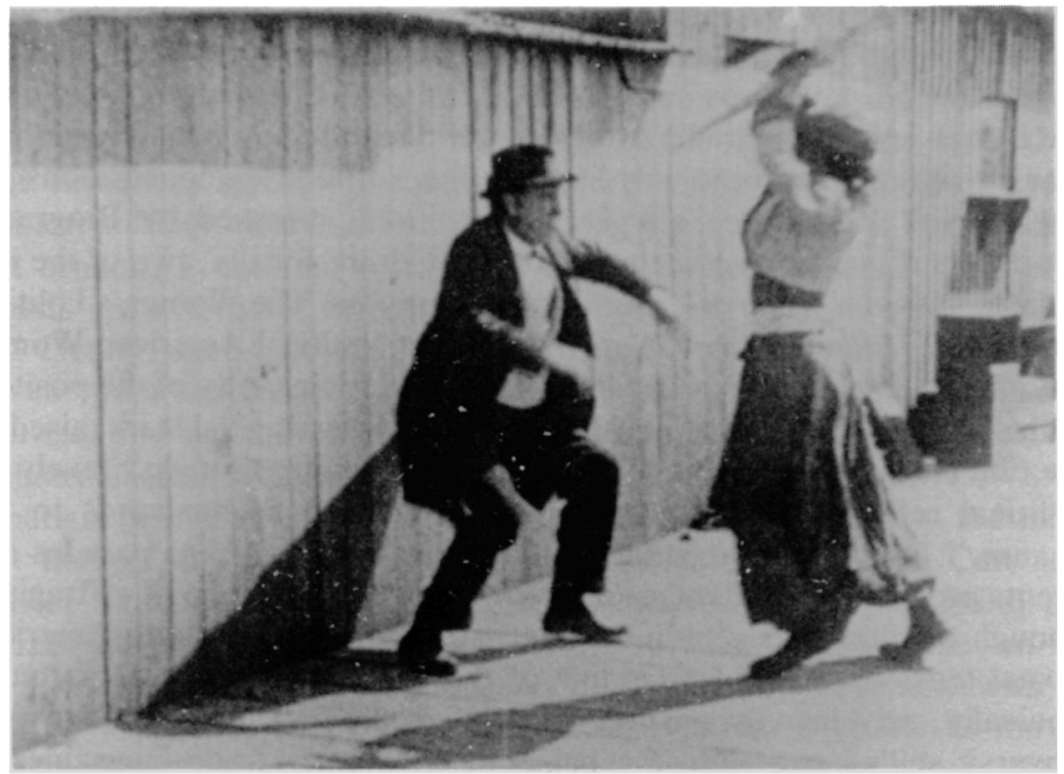
Day.

Charlie Chaplin, on the right, plays a suffragette who brutalizes a cringing man in A Busy

suffrage movement's own films raised issues about women's roles which are still debated today, and the silent films offer a fascinating excursion into American sexual politics. Unfortunately, very few of the early films have survived. When silent films lost their commercial viability within several years after release, the early film companies, eager for fast production and quick profits, carelessly discarded them. Often the companies themselves were too short-lived to maintain their films. The perishable silver nitrate stock on which the films were printed further reduced their chance of survival; thus those that exist today are rare cultural documents. Since they have been scattered across the country in often obscure film archives, the suffrage films have been sadly neglected by both film historians and suffrage movement scholars. ${ }^{1}$

The suffrage films screened for this study span a wide range of propagandic material. ${ }^{2}$ Two comedies, Edison's How They Got the Vote (1913)

${ }^{1}$ Cursory discussions of the woman suffrage films can be found in Marjorie Rosen, Popcorn Venus: Women, Movies, and the American Dream (New York: Avon, 1973); and Gretchen Bataille, "Preliminary Investigations: Early Suffrage Films," Women and Film, 1 (1973), 42-44.

${ }^{2}$ The suffrage films analyzed here are held by the Paul Killiam Collection, the Library of Congress, Classic Film Exchange, and Blackhawk Films. Newsreel material has also been preserved in a 1954 Canadian documentary, Women on the March, made by the National Film Board of Canada. 
and Charlie Chaplin's A Busy Day (1914), told moviegoers that masculine-looking suffragists would disrupt society and dominate men. A third comedy, A Suffragette in Spite of Himself (Edison 1911), exploited the British suffragists' radical activities and featured an antisuffrage hero who unwittingly becomes involved in the suffrage demonstrations. In 1912, Anita Loos's A Cure for Suffragettes, released by Biograph, satirized suffragists who neglected their children. Finally, two of the suffragists' own melodramas have survived the years. The Women's Political Union's 80 Million Women Want-? and the National American Woman Suffrage Association's Votes for Women speak poignantly of the position of the women's movement in 1912 and 1913, addressing the fears raised by the film industry's comedies. The suffragists' heroines fought bravely for political reforms, and converted their financés or husbands to the "cause." In addition, existing newsreel footage of suffrage parades and events provide a third dimension to the cinematic coverage of suffragism. Though the preserved film footage offers valuable insight into American sexual tensions, an understanding of the full impact of the films must, ironically, rely heavily on original printed material. The suffrage controversy spilled over into the pages of such early trade magazines as Moving Picture World, Motography, Variety, and Photoplay, and their reviews testify to the lively argument over women's rights which the suffrage films once delivered.

The first decade of the twentieth century was a pivotal period for both the suffrage movement and for the budding film industry. During this important era, the suffragists fought their opposition with arguments that women would usher in changes that the corrupt male political machinery resisted. Social problems of alcoholism, tenement conditions, sweatshops, urban overcrowding, and disease were addressed by the suffragists, most of whom represented the educated, upper-middle class. While progressive leaders supported the same reforms, they differed on the issue of woman suffrage. Woodrow Wilson refused to support votes for women until the very last years of the suffrage movement, and suffragists found themselves working for labor and social reforms alongside progressive politicians whose reformist policies ended at woman suffrage. More a frame of reference than a movement in itself, progressivism failed to unite the suffrage issue with wider reforms. ${ }^{3}$ Thus in the last years of its long history, the suffrage movement groped for new, more convincing arguments. While the suffragists pushed for reform, the cities' movie

\footnotetext{
${ }^{3}$ See Robert M. Crunden's essay in John D. Buenker, John C. Burnham, and Robert M. Crunden, Progressivism (Cambridge, Mass.: Schenkman, 1977). Also see Peter G. Filene, "An Obituary for 'the Progressive Movement,", American Quarterly, 22 (1970), 20-34. I have also referred to Robert M. Crunden, "The Progressive Achievement in American Civilization, 1889-1920," manuscript in progress.
} 
houses drew working-class audiences seeking escape from the harsh realities of urban life which suffragists sought to change. Young, dynamic film companies won crowds in ever-increasing numbers as new nickelodeons were built. By 1910, nearly 10,000 film theaters catered to large audiences across the country. Unfortunately, the suffragists had a far more difficult time in attracting working-class audiences. Ruth Hanna McCormick, a national officer for the NAWSA, remarked that suffragists spent most of their time giving speeches to each other in public. ${ }^{4}$ Clearly, such a strategy would not further the movement: by 1907 , eleven years had passed since any state had granted its female citizens suffrage, and the movement seemed to be losing momentum under the cautious leadership of Dr. Anna Howard Shaw, the president of NAWSA. ${ }^{5}$ Impatient with Shaw's conservative methods and inspired by the militant tactics of daring British suffragettes, Carrie Chapman Catt and Harriet Stanton Blatch (the daughter of Elizabeth Cady Stanton) organized the Women's Political Union in 1907. And when Pathe, an innovative young film company, began a new cinematic movement with its newsreels in 1911, the suffragists became even more visible as movie cameras caught their colorful marches and demonstrations.

It was the lively British suffragists, however, who captured most of the cameras' attention. In 1908 the suffragettes in England had already realized the vast capacity for publicity held by the burgeoning film industry. When they staged an important rally in Hyde Park, the women invited a film company to document the event. Apparently, this first suffrage news film appealed to a curious public; a trade journal claimed that the film's producers had " probably never played to a bigger house" than they drew with this footage. ${ }^{6}$ Later newsreels, eager to entertain as well as inform their audiences, publicized the movement's violence and militancy. For the first time, the public could actually watch suffragists at work, and the picture they saw was a sensational one. Newsreels like Suffragettes Again (Pathe 1913), which featured firemen fighting a blaze ostensibly set by British suffragettes, told American audiences first-hand of the uncontrolled forces which women's suffrage could unleash. Even the title of this newsreel seemed to sigh at the acts of these brazen women who repeatedly struck out at society.

${ }^{4}$ Terry Ramsaye, A Million and One Nights (New York: Simon and Schuster, 1964), 528; James S. McQuade, "Your Girl and Mine," Moving Picture World, 22, 7 Nov. 1914, 764.

${ }^{5}$ For accounts of the political and ideological history of woman suffragism in the United States, see Eleanor Flexnor, Century of Struggle (New York: Atheneum, 1971); and Aileen Kraditor, The Ideas of the Woman Suffrage Movement, 1890-1920 (New York: Columbia Univ. Press, 1965).

${ }^{6}$ Rachel Low, The History of the British Film, 1906-1914 (London: George Allen and Unwin, 1949), 151. 
The Gaumont Film Company caught one of the most sensational events of the suffrage movement when it sent a cameraman to film the British Derby in 1913. As the King's horse thundered past, Emily W. Davison threw herself under its hooves to protest women's inequality and became a martyr for the suffrage cause. The unexpected suicide turned what was to have been an ordinary newsreel into a tragic display of the anguish and frustration felt by suffragists. Pathe further capitalized on the public's fascination with the morbid. The company covered Davison's funeral in detail, easing a camera slowly over the faces of solemn women marching behind the casket. Only the dramatic moments of suffragism merited newsreel coverage. When film companies failed to find the militant activities of the British within the United States, they settled for less incendiary subjects such as New York suffragists painting political slogans on a wall ${ }^{7}$-an act which the film company may well have staged. The women's rational arguments were forgotten in the scramble for colorful newsreel material.

In 1912, one year after Pathe's newsreels had become a regular feature on nickelodeon programs, American women paraded down New York's Fifth Avenue and discovered film companies busily recording the event. At the time of the first suffrage parade in 1910, many conservative suffragists considered a parade to be such a radical departure from the ideals of soft-spoken, modest womanhood that they refused to march. By 1912, however, suffragists turned out in great numbers in a spectacular, dignified procession. The film industry's keen nose for the sensational found only well-dressed, respectable-looking women calmly marching down the street in numbers approaching 10,000. Footage from the newsreel captured the suffragists smiling and waving at the camera as they passed, perhaps well aware of the influence wielded by the new technology. This same footage found its way into both an antisuffrage comedy, Was $\mathrm{He} \mathrm{A}$ Suffragette? (Republic Films 1912), and the movement's melodrama, Votes For Women.

Despite their fascination with the lurid or titillating aspects of suffragism, the newsreels did not have a completely negative impact on the women's movement. The films introduced suffragists to nickelodeon audiences as real people rather than cartoon caricatures. Occasionally cameramen depicted the women in a sympathetic light. In a 1914 campaign report, one suffragist sounded bewildered at the attention that a newsreel crew paid her organizing efforts in Atlantic City. She announced that, during her meeting with the mayor, "the 'movies' took pictures of the meeting and had me pose especially for them with a great sheaf of

${ }^{7}$ National Film Archive Catalog (London: British Film Institute, 1965), 122. 
gladiolas. ${ }^{8}$ Whether the newsreels' image of suffragists was derogatory or sympathetic, suffrage became an immediate issue when it was projected on movie screens. The films might ridicule the suffrage movement, but its power could not be denied or ignored. Newsreels heightened the public controversy over suffragism with their larger-than-life images of the movement's women.

While the newsreels gave the movement dramatic publicity, antisuffrage comedies amused their audiences with authoritarian wives and emasculated husbands. With some variation, three broad themes emerged in the scores of suffrage comedies made in the pre-World War I era. The most popular formula featured militant women whose encounters with the world outside their homes soon sent them hurrying back to their families. A second pattern reversed the sex roles of the films' heroes and heroines, creating a brutal world in which women abused their husbands. Several comedies revealed a third theme which questioned the sexuality of cynical suffragists who attempted to destroy the romantic attachments of their younger, more attractive followers. Throughout the films, anxiety over the world of the future festered beneath the story lines. A perceptive film reviewer of 1911 wrote, "the richest field for farce comedy is not the musty past nor the inglorious future, but the gloriously uncertain future.", 9

In 1913, when Thomas Edison filmed How They Got the Vote, the future was indeed uncertain for the position of women in society. Capitalizing on the new vitality of both the American and British suffrage movements, Edison's comedy assured audiences that, though sinister suffragettes might try to ban romance from the world, ingenious young men would inevitably prevail. Set in England, the plot revolved around a love affair between the hero and a young woman, the daughter of a suffragist leader who wore a feather boa to hide the 'Votes for Women' banner stretched across her chest. The surviving footage reveals the girl's mother at tea with male political leaders. All was calm and proper until she whipped off the boa to reveal her banner, at which the wide-eyed men cowered against a wall in fear. The suffragist proceeded to lecture them, shaking her fists while they held up their trembling hands as if to fend off an evil force.

Indeed, Edison's suffragist looked evil. With an arrogant scowl, she spied on her daughter and the girl's fiancé, finally ordering the young man away. But the hero was not so easily defeated: using supernatural powers he conveniently obtained from a magician, the young man secured votes

8 “"Nation-wide Suffrage Day Draws Near," The Suffragist, 2, 25 April 1914, 7.

${ }^{9}$ Louis Reeves Harrison, "The Comedy of the Future," Moving Picture World, 8, 4 Feb. $1911,230$. 


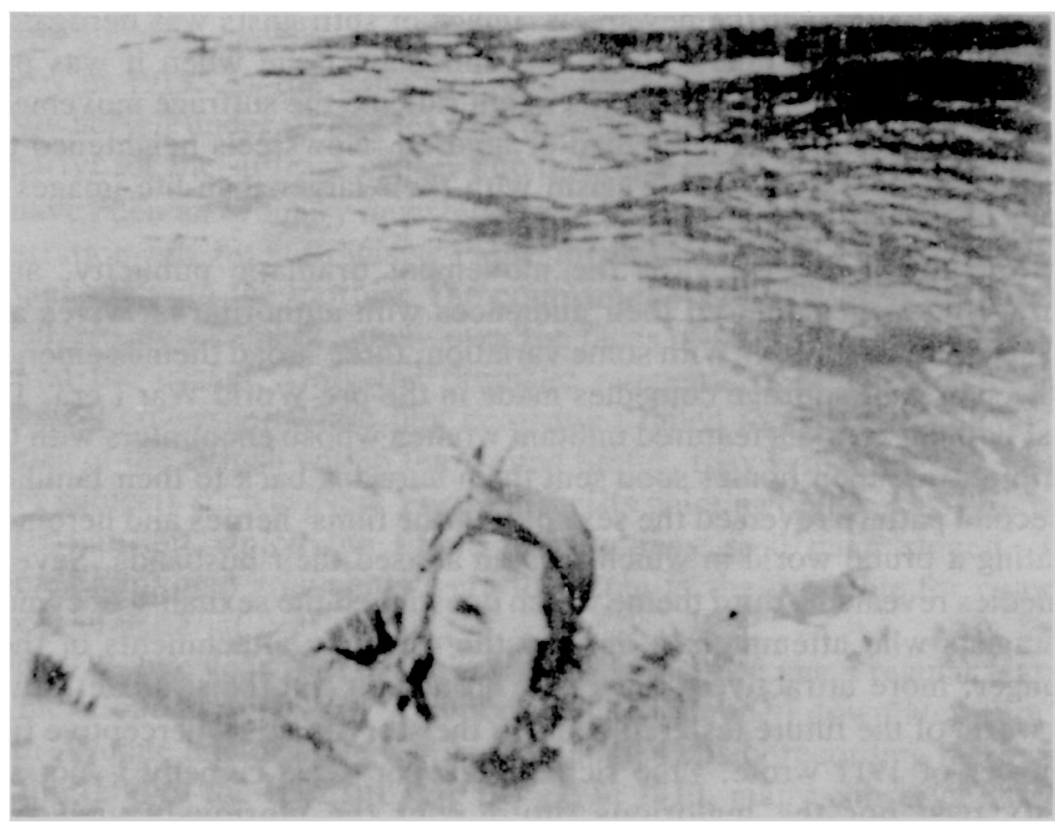

In the last scene of A Busy Day, the suffragette meets her demise after her humiliated male companion pushes her into the ocean.

for women. In a single act, he won both the hand of his lover and the gratitude of his future mother-in-law. Despite the determination of the domineering suffragist, it required the efforts of a wily man to win her political goal for her. Even then, of course, it was only through magical intervention that he succeeded. Edison thus added a unique twist to the traditional comic themes: this time the film's happy ending included both votes for women and a salvaged romance. How They Got the Vote managed to straddle the suffrage fence, presenting a stereotyped view of suffragists while it reconciled the family with women's political equality.

The following year, Charlie Chaplin's A Busy Day held no trace of ambivalence in its caricature of a suffragist. Originally titled $A$ Militant Suffragette, the film was retitled by the Keystone Company when the Pathe Company released an antisuffrage melodrama with an identical title in the same year. ${ }^{10}$ Making his first appearance in a woman's role, Chaplin played a coarse suffragette who rescued a political partner trying to disrupt a parade. With fists swinging and his skirt swirling above his head, Chaplin's suffragette took on the police singlehandedly, and then

${ }^{10}$ See John Stewart, comp., Filmarama I: The Formidable Years, 1893-1919 (Metuchen, N. J.: Scarecrow, 1975), 48, 242. 
suddenly realized that her male companion had turned his attentions to a more attractive woman. Chaos broke out as a jealous Chaplin fought to win her man back. But her struggle was short-lived: her companion pushed her off a pier into the ocean. Sputtering and spewing, Chaplin's caricature slowly sank, and no one came to her rescue. The final bubbles rising from the water's surface seemed to promise the last gasps of the votes-for-women movement.

Edison's A Suffragette in Spite of Himself (1912) allowed the suffragettes to have the final word. When two young boys pinned a 'Votes for Women' sign on the unsuspecting hero's back, antisuffragists taunted the confused man. He fought back frantically, resisting the police when they dashed up to arrest him. Suffragettes further complicated this "comedy of errors" as they descended upon the police to protect their "ally." But the bewildered gentleman emphatically assured the women that he was not interested in their cause, and staggered home only to find that his maid had impishly planted a 'Votes for Women' banner beneath his bourbon bottle. Again, the opportunistic Edison conveyed a double message: the "antis" he portrayed seemed as hysterical as the suffragettes. Earlier suffrage satires, however, made a less ambiguous statement. The stand-

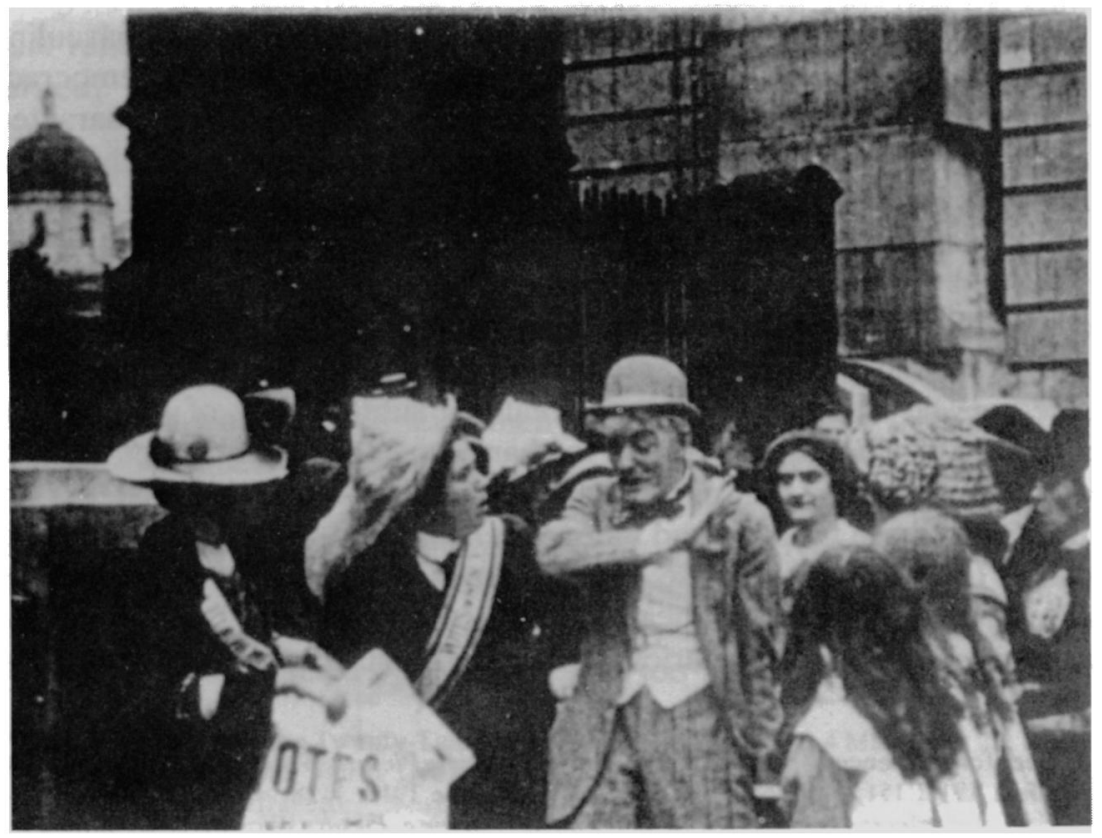

The hero of $A$ Suffragette in Spite of Himself emphatically assures his female rescuers that he is not interested in their cause. 
ard plots of such films as When Women Win (Lubin 1909), Will It Ever Come to This? (Lubin 1911), For the Cause of Suffrage (Melies 1909), and Was He A Suffragette? (Republic 1912) revealed suffragists victimizing hapless men. ${ }^{11}$

The most innocent "victims" of suffragism were the children in the early comedies. A Cure for Suffragettes (Biograph 1912) opened with women parking baby carriages outside their suffrage meeting. While their stranded babies wailed in their buggies, the suffragists plotted new strategies to win the vote. "Let us stop at nothing in our fight for something!" shouted the leader. Outside, a police officer noticed the deserted children, and pulled them down to the station in a caravan of baby carriages. Benevolent policemen comforted the babies until their mothers, finally heedful of their maternal "duties," snatched their children away. Here, the gentle officers of the law proved to be more sensitive to the children's needs than their militant mothers. Anita Loos's script left the final message ambivalent: the last title card read "but even a suffragette can be a mother."

Reviews of long lost comedies with titles such as A Day in the Life of a Suffragette (Pathe 1908), Oh! You Suffragette! (American Films 1911), The Reformation of the Suffragettes (Gaumont 1911), and When Women Vote (Lubin 1909) ${ }^{12}$ indicate that the film companies had stumbled upon a successful formula of satirizing suffragism. In these comedies, masculine suffragists unleashed a tidal wave of irrational forces that left democracy in shambles and the family revolutionized. But, like Chaplin's character, they inevitably discovered that cruel fates awaited them when they ventured outside their prescribed roles. These would-be heroines often found themselves in jail, or imperiled by such menacing threats as tramps or spiders during their political meetings. When A Determined Woman (Independent Motion Pictures 1910) reunited its suffragette with her family, the reviewer noted an important function of the comedies. "Intended for a comedy," he wrote, "this film is really a subtle study of life and the influences which may be invoked to change the apparently uncontrollable currents." 13 Against the quickening pace of "uncontrollable currents" of suffragism, these films tucked independent women snugly back into their families (or, in Chaplin's case, simply drowned her), informing their audiences that the growing political interests of women were merely temporary whims, typical of hysterical females. The suffragist would soon dis-

${ }^{11}$ See, for reference, "Stories of the Films,'” Moving Picture World, 5, 2 Nov. 1909, 769; 8, 21 Jan. 1911, 151; 5, 23 Nov. 1909, 581; 12, 22 June 1912, 1128.

${ }^{12}$ See, for reference, "Stories of the Films," Moving Picture World, 1, 22 June 1907, 252; 2, 2 May 1908, 401; 8, 25 Feb. 1911, 434; and 8, 8 April 1911, 787.

13 "Stories of the Films," Moving Picture World, 6, 25 June 1910, 1101. 
cover her inability to handle the world outside the home and families would emerge from the turmoil with their patriarchal authority confirmed.

Such conclusions would not have appealed only to male viewers. In 1912 , one female antisuffragist wrote that "our greatest strength lies in the accepted fiction of our weakness." Many women worried that suffrage would erode their traditional sources of subtle power. When the films asserted the helplessness of women, they reassured female audiences that the qualities they used to beguile and influence their husbands were still valid. Suffrage threatened the self-image of those women who feared the ramifications of voting extended far beyond the ballot, and certainly the comedies encouraged such anxiety. One women claimed that suffrage would not only rob women of their power over the family, but it might cost them their husbands as well. In her analysis, suffragism and divorce went hand in hand as independent women sounded the death knell for the family. ${ }^{14}$

Comedies titillated their audiences with a fascination over sex role reversals, focusing on the deepest fears roused by the suffrage movement and soothing them with cathartic laughter. In fact, the idea that woman suffrage would produce a nation of masculine women was no joke: the comedies' sex role reversals merely reflected the thinking of such antisuffragists as Robert Afton Holland, who proclaimed in 1909 that the vote would render women "ugly and coarse." The suffragists themselves, he charged, were "large-handed, big-footed, flat-chested, and thinlipped." 15 Preying on such fears, the comedies presented nickelodeon customers with a thematic circus of suffrage victims and villains. Audiences saw rebellious wives hurling food at their cowering husbands, women slugging each other over election returns, suffragists forcibly dressing men in diapers, and female sheriffs pretending to hang their terrified husbands. ${ }^{16}$ The world of the comedies spun about in confusion as men struggled for a steady footing in a society ruled by women. The films depicted women terrorizing men from coast to coast, from frontier towns to the streets of New York City. If the comedies were to be believed, suffragists were surging across the country leaving in their wake dazed men wondering what had happened to their wives.

The women's movement symbolized a greater issue than political equality; it swept the ancient struggle over sexual power out of psychic closets and into the public arena. No weapon was too subversive in the ensuing

${ }^{14}$ Ann Watkins, "For the Twenty-Two Million," The Outlook, 101, 4 May 1912, 29; Molly Elliot Seawell, The Ladies' Battle (New York: Macmillan, 1911), 110.

${ }^{15}$ Holland, "The Suffragette," Sewanee Review, 17, (July 1909), 282.

${ }^{16}$ These incidents were used in the plots of Calino Marries A Suffragette (Gaumont 1912), When Women Vote (Lubin 1907), The Suffragettes' Revenge (Gaumont 1914), and The Suffragette Sheriff (Kalem 1912). 
battle, and the comedies reveal a veritable arsenal of antisuffrage arguments. Their suffragist caricatures were irrational; they neglected or abused their families; they alternately represented anarchy or authoritarianism; most insidious of all, the women were unattractive manhaters whose sexuality seemed to be in question.

Michael Wood has written that film points out the unconscious worries of a culture; like dreams, the movies expose hidden anxieties and taboo subjects. Without sound to make images more concrete, the silent suffrage films created a nightmarish world of psychic fears. Men became powerless before witch-like, sinister women. But the comedies exorcised fear with humor, inflating sexual tension only to explode it with laughter. Rachel Low, a historian of silent film, found that the proliferation of suffrage comedies reflected the "hostility of the ignorant to anything new or strange, that hostility, hatred and fear which find their relief in jeers." The images of silly suffragettes parading across nickelodeon screens allowed audiences to dismiss suffragism as a ludicrous activity of misguided, foolish women. One of the comedies' heroes, who lost his lover to suffragists in The Suffragettes' Revenge (Gaumont 1914), perhaps stated it best: "the spectacle of the suffragettes," he announced on a title card, "would make me laugh if it did not make me cry." The two intense responses rose from the same discomfort, and comedies substituted laughter for tears. ${ }^{17}$

Suffragism became an increasingly emotional issue after the first decade of the twentieth century, and the films' sinister image of suffragists was a cinematic reflection of public alarm. A New York Times editorial of 1914 panicked over what it called "an advance in the reign of terror" created by "fiendish" women. Condemning Harriet Stanton Blatch's "deviltries," the writer charged that her followers were "afraid of nothing; they want what they want when they want it." 18 The antisuffrage comedies and melodramas brought such hostile political rhetoric to life.

This, then, was the climate in which the National American Woman Suffrage Association and the new Women's Political Union struggled to be heard sympathetically. When the suffragists answered the silent accusations of these films with melodramas of their making, the women attested to the rising power of cinema. Movie screens provided suffragists with a national forum from which to appease the public's anxiety over votes for women. Between 1908 and 1914, the peak era of suffrage films, the nation's movie theatres grew in numbers from around eight or ten thousand to fourteen thousand. ${ }^{19}$ Suffragists found that the lively new

${ }^{17}$ Wood, America in the Movies (New York: Basic Books, 1974); Low, History of the British Film, 177; "Stories of the Films," Moving Picture World, 15, 27 Jan. 1913, 1596.

18 "The Suffragists' Latest," New York Times, 11 Aug. 1914, 8.

${ }^{19}$ Ray Fielding, The American Newsreel, 1911-1967 (Norman: Univ. of Oklahoma Press, 1972), 65. 
entertainment form of the "photoplay" could be an exciting vehicle for their arguments. It was with high hopes of winning new support for their cause that the movement produced its four films.

Dramatic tactics, perhaps, could succeed where rhetoric had failed. Portraying suffragists as deeply moral, attractive women who were devoted to their families, the movement's fiction films presented their heroines as sympathetic characters to audiences accustomed to seeing masculine or hysterical suffragette caricatures. The suffragists already knew the value of dramatic devices in their state campaigns. In 1911, the year preceding the first suffrage propaganda film, California had been won largely due to the use of lively pageants and plays. Among the California State Campaign's subcommittees was one specifically concerned with "Dramatic Entertainments, Stereopticon Talks and Moving Pictures." The NAWSA convention report from California in 1911 announced that the subcommittee's " picture slides and stereopticon talks . . . were very effective, particularly in the outlying districts." ${ }^{20}$

A popular suffrage play, How the Vote Was Won, had proven to be an effective piece of propaganda and by 1911 suffrage groups across the country were acting out its scenes. The Suffragist, a weekly newspaper sponsored by Alice Paul's Congressional Union for Woman Suffrage, called the play "one of the finest arguments for suffrage ever written," and noted that it attracted "many who are fond of the drama and somewhat less fond of debate." The play featured a comic antisuffrage hero who reevaluated his position on women's rights when two female relatives quit their jobs and moved in with him, raising issues of women's rights to work. ${ }^{21}$

The idea of dramatic means for spreading the woman suffrage message had caught hold, and, by 1911, the suffragists had acquainted themselves with the relatively new technology of projection in their efforts to entertain as well as inform audiences. A "slide and lecture" show had become a popular new device. When the Equal Franchise Society held a "Suffrage Week" in February of 1911, the suffragists found that cooperative nickelodeon owners readily allowed them into theatres to address audiences with their slides. ${ }^{22}$ Unaware that suffragists had developed the slide show, a film journalist suggested that "every propagandist, suffragistic or otherwise, might achieve great results by getting his cause illustrated by means of lantern slides. . . ." ${ }^{23}$ Only a few weeks later, he noted with

${ }^{20}$ The Handbook of the National American Woman Suffrage Association and Proceedings of the 43rd Annual Convention (New York: NAWSA Publishers, 1911), 100-01. Hereafter cited as NAWSA Handbook.

21 "Suffrage Play," The Suffragist, 1, 20 Dec. 1913, 48; "How the Vote Was Won," The Suffragist, 2, 21 Feb. 1914, 7.

${ }_{22}^{2}$ NAWSA Handbook (1911), 23, 155.

${ }^{23}$ Thomas Bedding, "Propagandry and the Picture House," Moving Picture World, 8, 18 Feb. 1911, 347. 
surprise that

an enthusiastic lady suffragist has captured a downtown moving picture theatre, where she is showing lantern slides and talking the virtues of suffragism to large audiences. We are not going to say whether this is a step in the right direction but it is a straw which shows the direction of the wind. ${ }^{24}$

According to this writer, approximately one-third of the nation's population attended the movies every week! The "wind" was clearly directed toward exploiting this vast audience for the suffrage cause, particularly since moviegoers were primarily the working-class men and women whose support the suffragists lacked.

It seemed to be a logical next step for suffragists to enter the moviemaking arena; their dramatic use of plays and pageants had proven effective, and they were already addressing nickelodeon audiences. Trade magazines urged the use of film for reform. An article in 1912 might have further encouraged the suffragists, asserting that "the value of the moving picture as a means of agitating for the betterment of social conditions is self-evident. Nothing affects us more powerfully than the truth when it is preached in pictures." 25 The nation's leading suffragists must have agreed with this claim. In 1912 they began making films to circulate through the country's movie houses as well as for their own use in state campaigns.

In June of 1912, both the National American Woman Suffrage Association and the Women's Political Union released films starring attractive, sympathetic suffragist characters to counter the stereotype of masculine, irrational suffragettes perpetuated in the comedies. NAWSA, in conjunction with Reliance Films, produced Votes for Women, a melodrama contrasting reform-minded suffragists with a corrupt senator, while the WPU collaborated with American Films on Suffrage and the Man, a comedy satirizing a man who left his fiancée because of her belief in suffragism.

It was, perhaps, appropriate that the movement's only comedy should ridicule a man for disrupting a romance. Suffrage and the Man responded to the numerous comedies in which suffragists left their husbands or lovers. But even the suffragists' comedy cautiously played into stereotypes and conservative values. Its beautiful heroine vied against a conniving, jealous woman for her former lover, and finally won him back just as women got the vote. Romance was still the central concern of the women in Suffrage and the Man. An advertisement for the film displayed the happily reunited couple nestled cozily together, the heroine unmistakably labelled with her 'Votes for Women' parasol and banner. The most

${ }^{24}$ Thomas Bedding, "On the Screen," Moving Picture World, 8, 4 March 1911, 472.

${ }^{25}$ W. Stephen Bush, "The Social Uses of the Moving Picture," Moving Picture World, 12, 27 April 1912, 305. 
striking appeal to conservative moviegoers, however, appeared in the comedy's racist allusions to black male voters. Explaining his support of woman suffrage, the heroine's father asked, "My butler and my bootblack may vote-why not my wife and daughter?" The implication that women should vote because "butlers and bootblacks" could also revealed the class nature of the movement. Perhaps the suffragists played on the status anxieties of the average moviegoer when they presented suffragism as a "respectable" concern of the upper classes in Suffrage and the Man. The comedy spoke soothingly to the prejudices and fears of mainstream America to expedite the suffrage cause. ${ }^{26}$

Of the two films, however, Votes for Women created the bigger stir, possibly because two of the nation's most prominent suffragists appeared in it: Jane Addams and Anna Howard Shaw. The initial impetus for the NAWSA film came from the film industry, when Reliance Films approached Addams and Shaw to convince them that a movie could be a forceful argument for suffrage. ${ }^{27}$ Obviously, the young film industry had decided that both sides of the suffrage controversy could be profitable entertainment-Reliance had released a suffrage parody, Bedelia and the Suffragette, only a few months earlier. Shaw and Addams agreed to make a film only after much deliberation. Addams, in particular, had been a foe of the harmful world she felt the movies created. In 1909, she had warned that moving pictures were a "debased form of dramatic entertainment" that depicted "a primitive state of morality." ${ }^{28}$ The irony of her appearance in Votes for Women did not escape one reviewer, who wrote:

one of the significant facts in connection with this picture is that some of the ladies who appear in it at one time were to be classed as antagonistic to the moving picture. ${ }^{29}$

The times were changing, however, and Addams's mind had apparently changed with them. She and her colleague Shaw decided that film could be fought with film and old stereotypes of suffragists countered with a more realistic portrayal in melodramas.

Under the direction of Hal Reid, the two reels of Votes for Women turned the distinguished world of the United States Senate belly-side up and found it crawling with corruption. Beginning with actual suffragists speaking at a labor meeting, the film turned to a melodramatic portrayal of its heroines. The women opposed a villainous senator who owned a disease-ridden tenement and sweatshop. Only after the women converted

\footnotetext{
${ }^{26}$ Advertisement, Moving Picture World, 12, 8 June 1912, 796; "Stories of the Films," Moving Picture World, 12, 8 June 1912, 962.

27 "Anna Shaw and Jane Addams in Pictures," Moving Picture World, 12, 19 May 1912, 617.

${ }^{28}$ Jane Addams, The Spirit of Youth and the City Streets (New York: Macmillan, 1909 and 1930), 87.

29 "Anna Shaw and Jane Addams in Pictures," 617.
} 
his fiancée to suffragism did the senator, pressured by romance, finally realize the need for reform. The melodrama pointed to several controversial issues of the era, exposing the needs of working women, tenement dwellers, and neglected children. Left to men, the film implied, these wrongs would continue. Give the vote to women, and reforms would be enforced. Votes for Women established suffragists as the upholders of far higher ideals than government officials who profited from the very conditions the women sought to correct. The theme of woman as reformer was hardly new, however, to the movie screen. Audiences who watched The Reform Candidate in 1911 and The Stronger Sex in 1910 saw heroines exposing injustice or corruption. Though certainly not an overt call for woman suffrage, the theme of brave, moralistic women continued into 1913: Her Big Story and The Grafters featured a reporter and a secretary, respectively, who uncovered political graft.

Votes for Women thus followed a film tradition of sorts, but its call for woman suffrage was unique. Its closing shots left the message unequivocal, again using the footage of the 1912 suffrage parade in New York City that Was He A Suffragette? had exploited earlier that year. This time, of course, the context was different, and the Moving Picture World reviewer enthusiastically claimed that the parade sequence "makes a rousing finish to a picture that will undoubtedly be of great service to the advocates of women's rights all over America." 30

Apparently, this was an accurate prediction. At the 44th National American Woman Suffrage Association convention in late 1912, the women heralded the success of the new dramatic venture. One officer reported that "the play had been much in demand all over the country." A year later, the 45th NAWSA convention noted the diverse use of the film during the year's campaigns. In New Jersey, the Women's Political Union brought Votes for Women into the state and "secured its exhibition in many moving picture shows." In the Midwest, the Des Moines, Iowa suffrage club showed the film "in a small river front park near a bandstand where nightly concerts were given during Fair Week. Literally thousands of people saw the pictures and there were speeches two evenings to large crowds." At the Congregational Church of Appleton, Wisconsin, a smaller crowd paid five cents to see Votes for Women. Shown in nickelodeons, fairs, and churches, the movement's first melodrama impressed suffragists with its versatility and its ability to reach wide audiences. ${ }^{31}$

Encouraged by the success of Votes for Women, in 1913 the Women's Political Union produced a second suffrage melodrama entitled 80 Million

30 "Votes for Women," Moving Picture World, 12, 1 June 1912, 811.

${ }^{31}$ See convention reports in NAWSA Handbook (1912), 19, and (1913), 95, 101; Rev. E. Boudinot Stockton, "The Pictures in the Pulpit," Moving Picture World, 14, 28, Dec. $1912,1285$. 


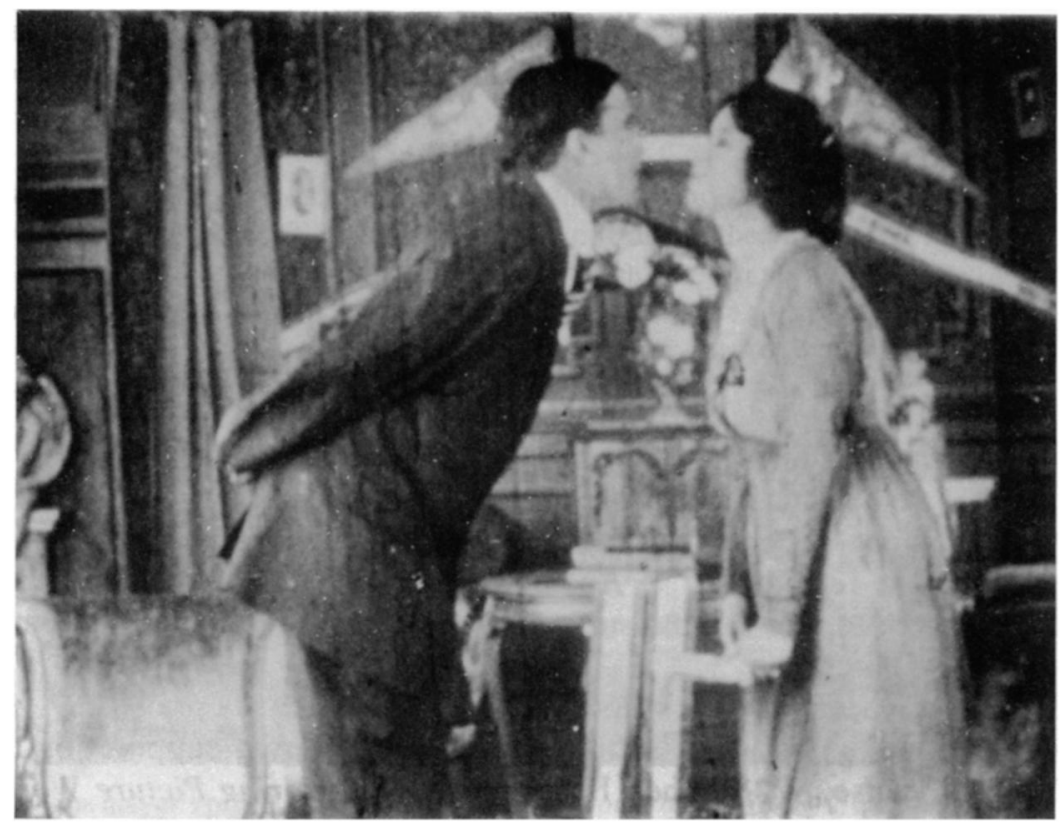

Eighty Million Women Want-? ended as the hero handed his suffragist fiancée a marriage license, proving to movie audiences that suffragists were just as interested in romance and marriage as other women.

Women Want-?, an apparent reference to a suffrage book similarly titled What 80,000,000 Women Want. The WPU, having worked with Eclair Films on Suffrage and the Man, turned to the newly formed Unique Film Company with a plot similar to that of Votes for Women. Like its predecessor, 80 Million Women Want-? featured an attractive young suffragist who reformed her lover, a lawyer involved in political corruption. Starring Emmeline Pankhurst and Harriet Stanton Blatch, who followed their more conservative colleagues Addams and Shaw onto the country's movie screens, this film depicted the staunchly moralistic suffragists waging war on the city's political boss and eventually driving him from power. Romance and politics again successfully merged in the melodrama: having destroyed the corrupt forces of the political machine, the women won suffrage and the heroine was reconciled with her reformed lover. As the Moving Picture World reviewer wrote, "both she and the hero look and act their best when they gaze upon the marriage license, which forms the finale of the story." 32

Ironically, an incident at the first screening of 80 Million Women Want-? provoked some of the tensions that the film sought to resolve. A

${ }^{32}$ W. Stephen Bush, "Eighty Million Women Want-?" Moving Picture World, 18, 15 Nov. 1913, 741. 
long delay in the arrival of the film had made the audience restless and Harriet Stanton Blatch tried to entertain the crowd with a talk in which she

humorously commented on the non-arrival of the man-made film which was supposed to have started for the showing at the Bryant Theater in a man-driven taxi, some short time previous and considerately pointed out to the man part of the audience that accidents happen at times even to men-at which the back row lost its last male occupants. ${ }^{33}$

A reporter noticed that the film's two-hour delay gave many press men an excuse to leave, "murmuring to themselves or to somebody else 'a previous engagement-I really can't wait,' and disappear(ing) in the direction of the nearest restaurant." ${ }^{34}$ Apparently, some nervous men found it uncomfortable to meet actual suffragists, particularly when they seemed as feisty as Blatch.

Despite the near disaster of its first showing, reviewers praised $80 \mathrm{Mil}$ lion Woman Want-? and subtly indicated their own support for the suffragists' cause. W. Stephen Bush, writing for Moving Picture World, hailed the film's exposure of political corruption. "This feature," he claimed, "gives a most attractive picture of the defeat of the old and the victory of the new idea in politics." This reviewer suggested that the melodrama would give audiences a "new idea" of suffragists:

Those who have looked upon the Votes-for-Women movement as the last refuge for old maids and cranks are due for a pleasant and agreeable disillusionment. The heroine of the story, though a stanch (sic) enough suffragette, is womanly from top to toe..$^{35}$

Here, then, was one of the film's most important messages. Another critic echoed Bush's thoughts in a column that found the film "an agreeable surprise." Instead of a lecture by dogmatic suffragists, 80 Million Women Want-? was "really and truly [a] story [about] a young lawyer in love with a pretty girl.", 36

Political expediency demanded that even the most radical suffragists - and Pankhurst's militant activity in England placed her in the front ranks of the radicals-portray their cause in a nonthreatening manner in the film, upholding rather than subverting dominant social values.

\footnotetext{
${ }^{33}$ Anon., "What 80 Million Women Want?" Motography, 10, 29 Nov. 1913, 407.

${ }^{34}$ Ibid., 407.

${ }^{35}$ Bush, "Eighty Million Women Want-?" 741.

36 "What 80 Million Women Want?" 407.
} 


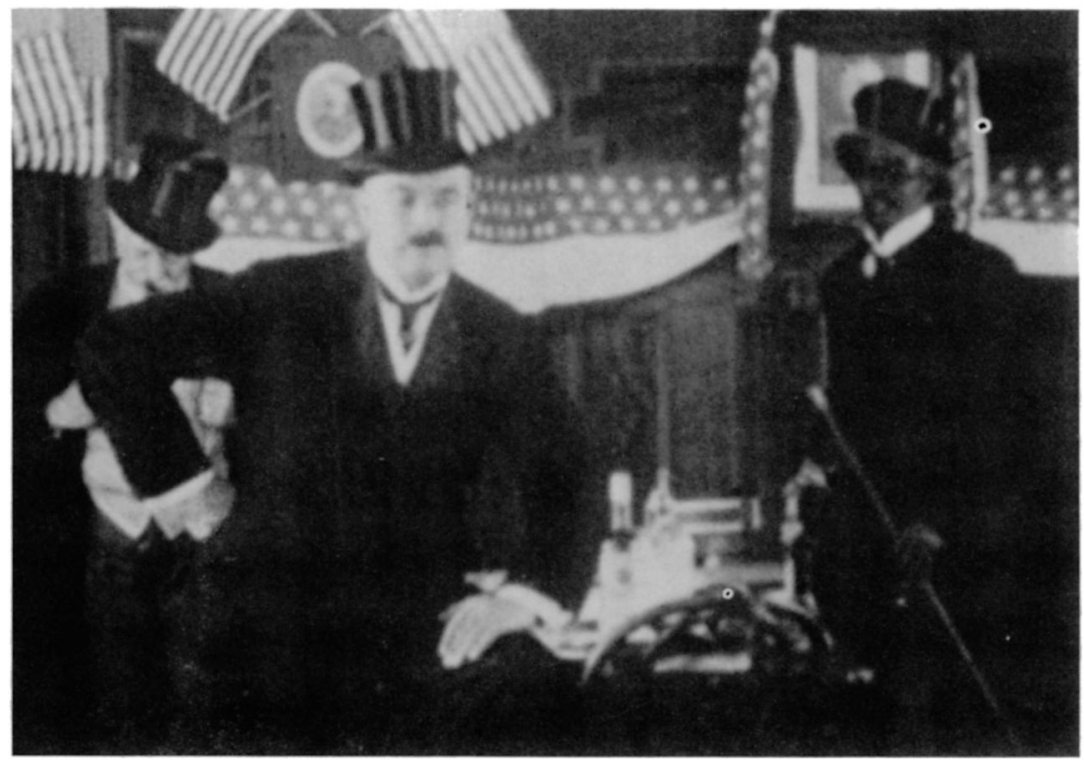

In the mayor's office, the villains of Eighty Million Women Want -? plot their next strategy against the feisty suffragists. On the right, the black henchman reminded audiences that black men could vote while white women remained politically powerless. Even the most radical suffragists appealed to racist attitudes to win support for woman suffrage.

Again, the WPU made racist allusions to support votes for women. Scenes of the political boss's office included a black henchman, outfitted in top hat, tails, and cane, who pompously puffed on his cigar. The implication was clear: a black man held political power while white women were denied the vote. In her analysis of the suffrage movement's arguments, Aileen Kraditor has noted that the women appealed to racist impulses in their campaign for the vote, questioning a society that would grant the vote to black men but not to white women. ${ }^{37}$ The Women's Political Union catered to dominant biases to expedite its cause.

Nuances, however, abounded in 80 Million Women Want-?. One scene revolved around an episode in which the political boss selected a suffragist infiltrator for his secretary over a long line of other applicants because, according to the title card, he was "impressed with her appearance." The suffragists subtly conveyed a double message: a suffragist could easily stand out in a crowd with her beauty if a man were foolish enough to hire her on the basis of her looks. This artful scene told audiences that, while suffragists were attractive women, this was an unfair standard of judgment that belonged to the mentality of corrupt politicians.

${ }^{37}$ Kraditor, Ideas of the Woman Suffrage Movement, 25. 


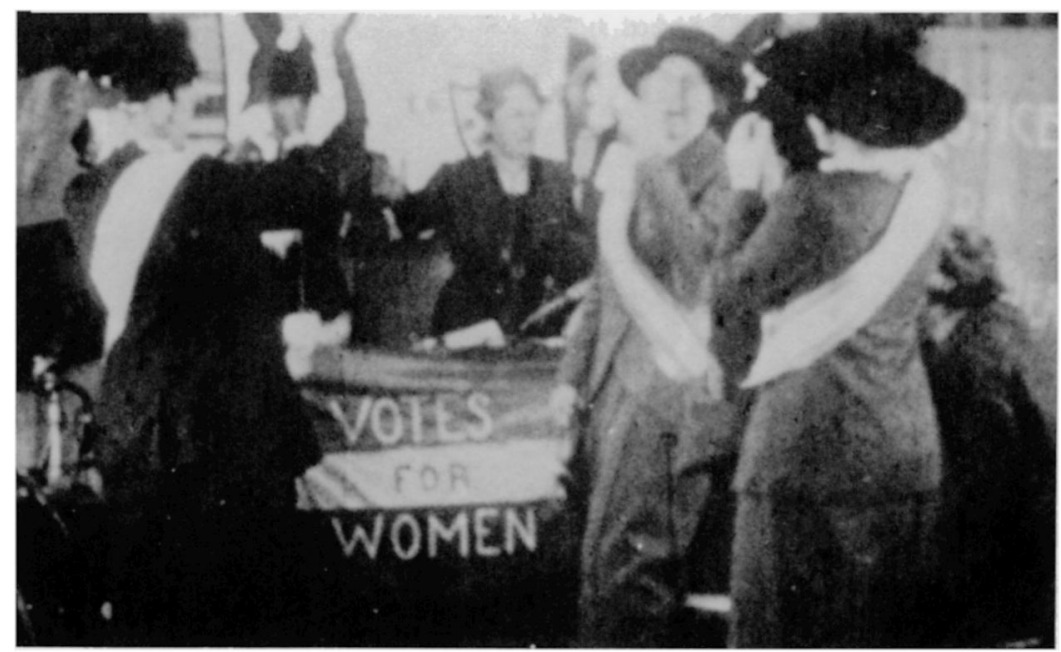

The Women's Political Union celebrates winning the vote in one of the last scenes of Eighty Million Women Want -?. Harriet Stanton Blatch is in the center behind the 'Votes for Women' sign.

Advertisements for the film expressed its dual images of suffragists. A full-page ad in Moving Picture World described the plot as "showing the pernicious activity of the 'boss' opposed by a beautiful 'Suffragette' who by a clever bit of detective work, saves her lover from jail, and who causes the boss's downfall by the aid of the SUFFRAGE PARTY. ${ }^{\prime 38}$ If the image of rebellious but lovely suffragists failed to get bookings for the film, the ad continued with a pitch to commercial buyers that hailed 80 Million Women Want-? as "the biggest money-getter of a decade" and claimed that "no more advertised personages can be found to-day" than the film's stars, Pankhurst and Blatch.

Pankhurst was, indeed, a much "advertised personage" in 1913, and her numerous arrests piqued the public's interest in this seemingly notorious woman. When the WPU released 80 Million Women Want-? in November of 1913, Pankhurst travelled on the east coast speaking to packed houses on women's rights. On November 24 , two weeks after the release of her film, the auditorium where she spoke was so full that over one thousand people had to be turned away. ${ }^{39}$ The mass audiences Pankhurst attracted in 1913 reflected recent gains which the suffrage movement had made. Five states granted women the vote between 1910 and 1914 , a rapid acceleration of progress over the fourteen years prior to 1910, when suffrage failed to gain even a single state. And, for the first time, Congress debated woman suffrage in 1913. Representatives to the NAWSA convention in November of 1913 excitedly discussed the movement's new momentum and its growing use of dramatic propaganda.

38 Advertisement, Moving Picture World, 18, 8 Nov. 1913, 626.

39 “'Big Throng Hears Mrs. Pankhurst," New York Times, 25 Nov. 1913, 3. 
One woman reported that "suffrage in graphic and dramatic form is more than ever in demand." ${ }_{40}$ The suffragists used dramatic forums wherever they found them: at a showing of a play, Her Own Money, at the Belasco Theatre in early 1914, suffragists decorated the theatre with colorful banners and streamers. ${ }^{41}$ In Rhode Island, suffragists held a "Theatre Day," when "every theater and moving picture house is asked to present a suffrage play; to have a suffrage speaker between the acts; to run a moving picture film or in some other way recognize suffrage day." 42

Commercial interests soon noticed the lucrative potential for profit in suffragism's dramatic tactics. After the release of Votes for Women in 1912, NAWSA found 1913 a boom year for publicity opportunities. The convention minutes of that year noted a rise in "propositions from people outside the suffrage movement for raising sums of money by combining commercial enterprises with suffrage work." Film industrialists, for whom profit mattered far more than politics, were eager to work with suffragists at the same time they were producing an abundance of suffrage comedies. Thomas Edison, whose company produced numerous suffrage parodies, is reported to have collaborated with NAWSA to make a "talking-moving-picture reel" for use in suffrage campaigns. The shrewd Edison may have been among those first in line at the suffragists' door when dollar signs appeared in movement propaganda. ${ }^{43}$

NAWSA proved so receptive to the film industry's new approaches that in 1914 the organization had two films underway at once, each unknown to the makers of the other. Both films were planned on grand scales to surpass the earlier melodramas. Noting that the Women's Political Union had just released 80 Million Women Want-?, the more conventional suffragists of NAWSA competitively claimed that the Association was devising "a very big ambitious moving-picture plan, partly worked out, which will quite excel [sic] any previous thing of the sort." It is an indication of NAWSA's confused leadership and lack of communication that the suffragists had to abandon this film when they discovered that one of their national officers, Ruth Hanna (Mrs. Medill) McCormick, was close to completing another film, Your Girl and Mine. Unaware of the film planned by NAWSA headquarters in New York, McCormick had collaborated with Lewis J. Selznick's World Film Company without notifying her colleagues. An undercurrent of frustration with NAWSA tactics surfaced in her statement on the origins of Your Girl and Mine. "Realizing that the suffragists . . . spend most of their time talking to each other in public, I felt it was necessary to try and originate a means of really reaching the public." ${ }_{44}$ NAWSA's miscommunications over the

${ }^{40}$ NAWSA Handbook (1913), 20.

41 "Congressional Union Campaign Propaganda Work," The Suffragist, 2, 10 Jan. 1914, 2.

${ }^{42}$ "'The Nation-Wide Suffrage Day," The Suffragist, 2, 18 April 1914, 6.

${ }^{43}$ NAWSA Handbook (1913), 20, and (1914), 45.

${ }^{44}$ McQuade, "Your Girl and Mine," 764. 
films, however, indicated that they should have spent more time talking to themselves in private.

Though the suffragists of 1914 had produced three films, made numerous slide shows, and had frequently spoken in person before nickelodeon audiences ${ }^{45}$ McCormick hinted that the movement had not yet used film to its full potential, and she immodestly touted her film as the Uncle Tom's Cabin of the suffrage movement. She envisioned a melodrama that would wring tears from its viewers and sway hearts to the plight of powerless women. Determined that her film would succeed, she shared power over the film with the director Giles Warren, casting some of the actresses and actors herself and conferring daily with Warren during production. ${ }^{46}$

McCormick's first goal for the film was that it "would appeal to every man and woman regardless of whether they knew anything about the suffrage movement or cared anything about it." ${ }_{47}$ In an effort first to draw crowds and second to argue for suffragism, Your Girl and Mine blended lively entertainment with propaganda. The melodrama filled seven reels with spectacular action, following the troubled marriage between a wealthy young woman and her abusive husband. When the husband used the heroine's money to buy liquor, the title card quoted his dramatic lines: "I am absolute master here," he told his wife, along with "under the law your money is also mine." Upon the death of the manipulative husband, the heroine discovered that her problems had just begun, for the villain had maliciously bequeathed their two daughters to their paternal grandfather. But the heroine's Aunt Jane, a suffragist described as "the good angel of the helpless and downtrodden," secured a court ruling and rescued the children from the clutches of their grandfather, who had put one of them to work in a cannery. ${ }^{48}$ In the final scenes, the governor signed a bill granting women the vote, assuring the female half of the population that they would be able to protect their rights. Your Girl and Mine's happy ending repeated the conclusions of all three previous suffrage films: after women won the vote, the beautiful heroine headed to the altar with the state's lieutenant governor, who had converted to the suffrage "cause."

Apparently, the victimized heroine of Your Girl and Mine appealed to the compassion of audiences, as she conquered a legal system that granted men total power over the lives of women and children. The film

\footnotetext{
${ }^{45}$ See NAWSA Handbook (1914), 113, 137, 171, 172.

${ }^{46}$ James S. McQuade, "Chicago Letter," Moving Picture World, 21, 26 Sept. 1914, 1782.

${ }^{47}$ McQuade, "Your Girl and Mine," 764.

${ }^{48}$ Original synopsis of Your Girl and Mine, ms., Motion Picture Division, Library of Congress.
} 
touched the early film theorist and poet Vachel Lindsay. He praised the film's symbolic figure of the suffrage movement, a woman labelled the "Goddess of Suffrage," who entered the melodrama "at critical periods, clothed in white, solemn and royal," to point out "the moral of each situation." ${ }^{49}$ Lindsay noted that the character found a real-life counterpart in Jane Addams, doing "justice to that breed of woman amid the sweetness and flowers . . . of the photoplay story." The suffragists understood that thorny subjects could be concealed in "sweetness and flowers," and, as far as the reviewers were concerned, their hearts were won. Struck by the beautiful suffrage "goddess," one reviewer surmised that ". . . if all suffragettes were as fair to look upon, it is safe to say that 'Votes for Women' would be a reality in every state in the Union today." ${ }_{50}$ The suffragists who chose attractive actresses to play their film counterparts recognized that physical beauty could win men's attention where arguments often failed. A Photoplay journalist even nominated his favorite actress for future suffrage films: William Henry yearned to see Cleo Madison in a suffrage melodrama, and he claimed that "Jane Addams and other loyal suffragettes are overlooking an awfully good bet in Cleo Madison. With the lovely but militant Cleo at their head, the suffragettes could capture the vote for their sex." 51

The positive reception of Your Girl and Mine initially suggested that attractive heroines and appeal to emotionalism could win the movement new support. When McCormick first showed her prized film in Chicago, the town's most prestigious citizens filled the theatre and enthusiastically applauded its dramatic title cards. The New York Times publicized the film's "ga!a opening performance" and the "unjust social conditions" it exposed, while Moving Picture World claimed that Your Girl and Mine proved that "moving pictures . . . will accomplish more for the cause than all that eloquent tongues have done since the movement was started." Everything pointed to success for the melodrama: press coverage was thorough and positive, audiences responded strongly, and Your Girl and Mine was scheduled to tour the nation's commercial theatres. ${ }^{52}$

Unfortunately, after all its publicity and expense, the suffrage movement's "Uncle Tom's Cabin" never fulfilled its high expectations. A solitary footnote in Ida Husted Harper's volume of the massive History of

\footnotetext{
${ }^{49}$ Lindsay, The Art of the Moving Picture (New York: Macmillan, 1922), 230-31.

50 Anon., "Has Initial Showing,"' Motography, 12, 31 Oct. 1914, 589.

${ }^{51}$ Henry, "Cleo the Craftswoman," Photoplay, 9, Jan. 1916, 109.

52 Anon., "Has Initial Showing,', 589; "Suffrage Play On Road,' New York Times, 21 Dec. 1913, 9; McQuade, "Your Girl and Mine," 764; "Suffrage Play On Road,' 9.
} 
Woman Suffrage barely nodded to the film, briefly commenting that McCormick "spent a large amount of time and money on this play, hoping it would yield a good revenue to the [NAWSA], but the arrangement with the Film Corporation proved impossible and it finally had to be abandoned." ${ }^{53}$ No further details of the schism were offered. The footnote is a sad testimony to the historical neglect given the suffrage films even at the hands of the movement's own historians. Suffrage archives reveal no additional information on the conflict between McCormick and World Films that relegated the film to noncommercial showings.

It must have been with great disappointment that McCormick presented her film as a gift to NAWSA in 1915 at the Association's 46th Convention, where it was placed on the nightly entertainment program. ${ }^{54}$ Her criticism of the movement as "suffragists talking to themselves" had become regrettably true of Your Girl and Mine. Though the film proved to be a financial disappointment, suffragists used it in their state campaigns and it even found its way into Canada, where the Montreal Suffrage Association showed it for fund-raising and publicity. ${ }^{55}$ The failure of Your Girl and Mine probably discouraged the suffragists; while they continued to use theatres for their slide shows, ${ }^{56}$ the suffragists apparently made no other films.

The effect of the suffrage movement's films on winning support for their cause is difficult to determine, but they are invaluable today for the picture they paint of a society caught between Victorian mores, progressive issues, and the impulse toward freer sex roles. The weapons wielded by both sides of the suffrage issue surface in the films. Myth was fought with myth, as the suffragists accepted the dominant image of women as morally superior and used it to their own advantage. The suffragists stepped onto the traditional "pedestal" and it became a soapbox from which they preached, urging that women's inherent ethical sensibilities could not be wasted solely on the family when male-run politics were rampant with corruption.

Thus the contradictions that characterized the suffrage movement in the twentieth century emerged repeatedly in the silent films. Conservative ideas of female superiority, upper-class benevolence, and racial issues

${ }^{53}$ Ida Husted Harper, ed., History of Woman Suffrage (New York: J. J. Little and Ives, 1922), 5:425.

${ }^{54}$ NAWSA Handbook (1915), 17.

${ }^{55}$ Catherine Lyle Cleverdon, The Woman Suffrage Movement in Canada (Toronto: Univ. of Toronto Press, 1950), 223.

56 "The Election Campaign," The Suffragist, 4, 21 Oct. 1916, 5. 
surfaced alongside demands for wider roles for women, the dismantling of political machines, and attention to the needs of the working classes. The image of men in the movement's films fluctuated between one of villainous tyrants and weak-willed, insensitive "heroes" who needed women to elevate them. The suffragists' films both lectured male audiences on their inferior moral status, and catered to male egos with attractive actresses. According to the films, men needed women to care for them and the sharpwitted, beautiful suffragists could do the job best. Though the movement bowed to the expectations of movie audiences with attractive heroines, racist implications, and fairy-tale romance, an angry undercurrent rumbled beneath its cinematic gestures of conciliation. The frustrations and resentment that accumulated against a male power structure during the long suffrage struggle seethed beneath the movement's films.

Several later commercial melodramas applauded the suffragists' long persistent efforts for political equality, continuing the appeal for votes for women. The Woman in Politics (Thanhouser 1916), One Law for Both (Abramsom 1917), and Maurice Tourneur's spectacular Woman (1918) raised issues surrounding the political and economic inequality of women. It is perhaps not surprising, however, that the film debate over suffragism ended in 1919 with a comedy that reflected ambivalence over women's changing roles.

Experimental Marriage (Select Pictures) told a different story about independent women. Starring Constance Talmadge, this comedy featured a newly married couple who lived together only on weekends, since the wife's suffrage work demanded her full attention during the week. Marriage and a political career belonged in two separate worlds in Experimental Marriage. Described by one reviewer as a "thoroughly modern young woman of lovable disposition," ${ }^{57}$ this flighty heroine finally sacrificed her work for a traditional marriage.

Thus the early comic themes of antisuffrage parodies survived World War I. If independent women were not members of a strange third sex, then they were indecisive, silly creatures who needed the love and guidance of a patient man. On the screen world of 1919, when woman suffrage was imminent, a comic suffragist could be attractive and "lovable." Experimental Marriage, however, indicated that the country would defuse the new political role of women by attaching an image of helplessness and irrationality to these would-be independent women. This last comedy 123.

${ }^{57}$ Hanford C. Judson, “Experimental Marriage," Moving Picture World, 40, 5 April 1919, 
made the final film statement on suffragism: America could tolerate "liberated" women as long as they hid their strength behind a guise of frailty and indecision. Overt power would remain unacceptable for women in the decades to come.

From their earliest years, the movies capitalized on sexual politics in America. Suffrage comedies and melodramas offered their audiences far more than entertainment when they reflected and then magnified sexual tensions, and theatre screens became a battleground for an ideological war that often forgot the real issue of woman suffrage. The suffrage debate set loose sexual apprehensions that extended far beyond the ballot and shook the roots of masculine and feminine identity. A brazen young film industry stepped without hesitation into the midst of the conflict for both profit and propaganda; in the process it exposed the insecurities of a nation of moviegoers.*

* The author wishes to thank the Bette Clair McMurray Foundation of Dallas, Texas, for grants subsidizing the acquisition and screening of the films discussed in this article. 